\title{
FIRST SASKATCHEWAN RECORD OF WESTERN GREEN HAIRSTREAK AND FIFTH RECORD OF ANCILLA DOTTED BLUE
}

Dale G. Hjertaas and Paule Hjertaas 15 Olson Place

Regina, SK S4S $2 \mathrm{~J} 6$

Finding a rare butterfly is, by definition, rare. Finding two rare species on the same plant is, therefore, very special.

On 19 June 2019, we hiked the 70 Mile Butte Trail in the West Block of Grasslands National Park. We started the trail at 06:28 $\mathrm{h}$ and were almost back to the trail head at 09:12 $\mathrm{h}$ when we noticed two butterflies on the same Yellow Umbrellaplant (Eriogonum flavum). As the butterflies were unfamiliar, we took photos for later identification.

The bright yellowish green underwing with no visible white lines and only a small bump on the hindwing instead of a tail, show the first butterfly to be either a female Western Green Hairstreak (Callophrys affinis) or a Sheridan's Hairstreak (Callophrys sheridanii). Note that some authors ${ }^{1,2}$ treat $C$. affinis as part of the Bramble Hairstreak (C. dumetorum), while others treat $C$. dumetorum as a separate species found west of the Rockies.

The Western Green and Sheridan's Hairstreaks are western species with their Canadian ranges reported as southern British Columbia and extreme southwestern Alberta for the Sheridan's Hairstreak and the southern interior of British Columbia for the Western Green Hairstreak. ${ }^{3}$ iNaturalist shows the closest vetted American record for $C$. sheridanii near Babb in northwestern Montana about $435 \mathrm{~km}$ from 70 Mile Butte Trail, with the next closest records at Yellowstone National Park in NW Wyoming about 520 km from 70 Mile Butte. The closest American records of $C$. affinis in

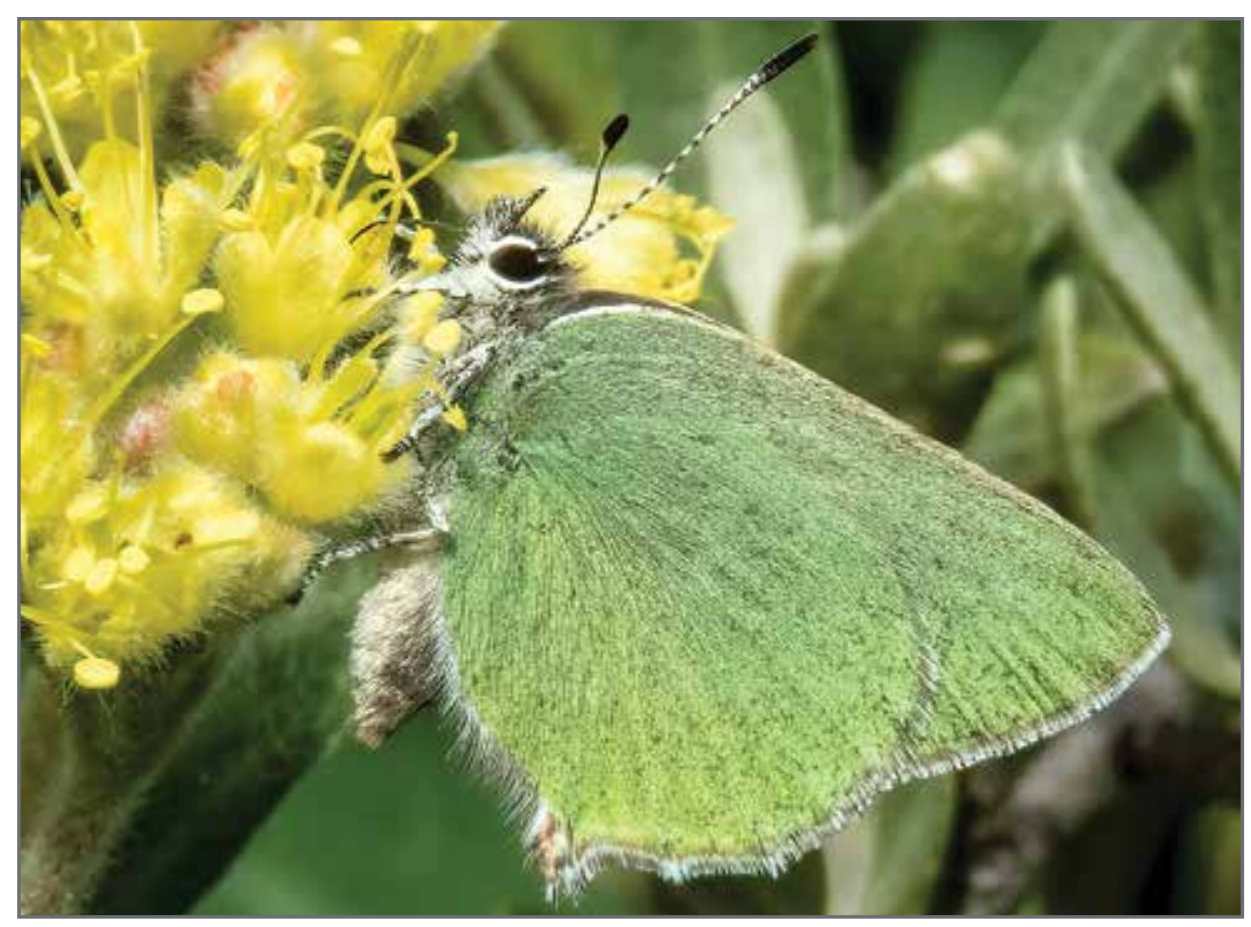

Western Green Hairstreak (underwing). Photo credit: Paule Hjertaas.

iNaturalist are also in the northwestern part of Yellowstone National Park, about $520 \mathrm{~km}$ from 70 Mile Butte. Range maps in Butterflies through Binoculars show both species' ranges extending into southwest Montana, with a dot indicating a small disjunct population of Sheridan's Hairstreak in southwestern North Dakota. ${ }^{2}$ Either species would be significantly outside its known range, though the location in North Dakota would make Sheridan's hairstreak seem somewhat more likely to be found in Saskatchewan.

Several characteristics are useful in identification. The colour of the underside is described as bright yellowish green in C. affinis as opposed to bright or dark green in C. sheridanii. ${ }^{3,4}$ Sheridan's Hairstreak has a more prominent post median white line across the underside, while this is largely lacking in the Western Green Hairstreak. 3,5,6 However the post median white line may be reduced or lacking in C. sheridanii. ${ }^{5}$ Nonetheless, at Yellowstone National Park, one of the closest locations where both species regularly occur, the presence of the white median line on forewing and hindwing is considered a distinguishing feature of Sheridan's Hairstreak ${ }^{1}$ and the absence of this line or its being broken into faint marks distinguishes $C$. affinis. The fringe on the hind wing of $C$. sheridanii is often dark at the end of the cubital veins (two veins on the lower part of the wing) while $C$. affinis has pale fringes. ${ }^{4}$ Based on the yellow green colour, the fact the white line across the hind wings is almost totally lacking and the pale fringe with very little black marking on the fringe or the veins, we concluded this was a Western Green Hairstreak (C. affinis).

This is the first record of this species for Saskatchewan. The record and photos have been filed on eButterfly as EB-383145 and the eButterfly vetters endorsed the 


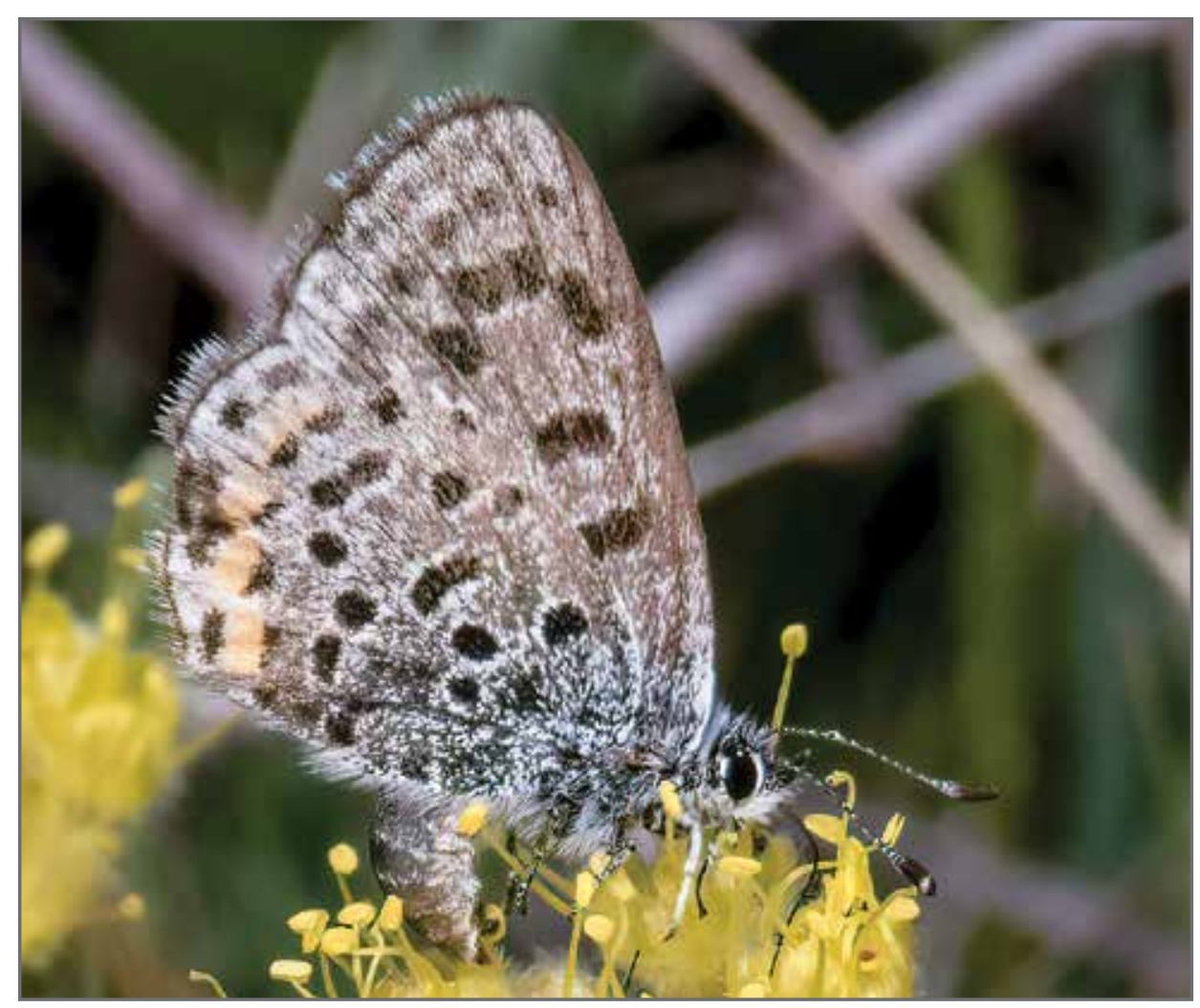

Ancilla Doted Blue (underwing). Photo credit: Paule Hjertaas.

identification. Because of the rarity of the observation and challenging identification we also posted photos on iNaturalist (27393787) and BugGuide (1680047) where they were also vetted.

The Western Green Hairstreak has only been reported in Canada from the Okanagan Valley of British Columbia, where it is found in sagebrush and meadow habitats. ${ }^{3}$ The main larval food plant is Eriogonum heracloides. ${ }^{3}$ A 1994 review of the status of butterflies in British Columbia suggested the species was vulnerable due to its restricted range and pressures from grazing, logging and urbanization. ${ }^{7}$ The British Columbia Conservation Data Centre categorizes it as S3 (Special concern or vulnerable) and G5 (Globally secure).

The grey underside with two rows of dark spots near the margin of the wings and orange spots between those rows of dark spots on the hindwing identify the second butterfly as an Ancilla Dotted Blue (female), Euphilotes ancilla, also called Rocky Mountain Dotted Blue ${ }^{3}$ and Spotted
Gollop). That makes our observation the fifth record for Saskatchewan.

Ronald Hooper collected the first Alberta record on 18 June 1963 in the Alberta Cypress Hills. ${ }^{3}$ The Ancilla Dotted Blue has also been reported in short grass and shrubby areas in coulee badlands in the Milk River-Lost River Area of Southeastern Alberta. ${ }^{9}$ The species is widely distributed in the Western United States. ${ }^{3}$

We gratefully acknowledge Mike Gollop's assistance in providing the previous records of the Ancilla Dotted Blue and the many valuable suggestions from an anonymous reviewer.

1. Debinski, Diane M. and James Pritchard 2002 A Field Guide to the Butterflies of the Greater Yellowstone Ecosystem. Roberts Rinehart Publishers, Lanham, Maryland.

2. Glasberg, Jeffrey 2001 Butterflies through Binoculars: The West. A Field Guide to the Butterflies of Western North America. Oxford University Press, Inc. New York, New York.

in this species while they form a continuous band in the most similar species, the Square Spotted Blue, Euphilotes battoides. ${ }^{3}$ The upper side is brown with a row of connected orange spots on the hindwing.

The butterfly appeared to be laying eggs in the Yellow Umbrellaplant flowers. You can see the abdomen curved down into the flower on the photo. Various species of Eriogonum are reported as the preferred foodplant for the caterpillars. ${ }^{3}$ This record has also been filed with and vetted by eButterfly, record EB-37801.

The first Saskatchewan specimen of Ancilla Dotted Blue was taken at Val Marie on 25 June 1968 with a second at Rosefield on 26 June 1968. ${ }^{8}$ These specimens are in the collection of the Royal Saskatchewan Museum. There are two other Saskatchewan records, one taken 1 July 1966 by J. Bernard Gollop and Mike Gollop at Matador and one taken by Mel Fitch at Eastend on 31 May of a year between 1995 and 1999. These two specimens are in the Gollop collection (pers comm Mike
3. Layberry, Ross A., Peter W. Hall and J. Donald Lafontaine. 1998 The Butterflies of Canada. University of Toronto Press, Toronto, Ontario.

4. Howe, William H 1975 The Butterflies of North America. Doubleday and Company Inc., Garden City, N.Y.

5. Anonymous. Butterflies of North America: Butterflies of Montana. http://www. abirdshome.com/resource/mt/toc.htm

6. LaBar, Caitlin 2016 Species Profile: Green Hairstreaks. http://northwestbutterflies. blogspot.com/2016/03/species-profile-greenhairstreaks.html

7. Guppy, C.S., J.H. Shepard, and N.G. Kondla 1994. Butterflies and Skippers of Conservation Concern in British Columbia. Canadian Field-Naturalist 108(1):31-40

8. Hooper, Ronald R. 1973 The Butterflies of Saskatchewan. Museum of Natural History, Saskatchewan Department of Natural Resources, Regina, Saskatchewan.

9. Smith, W.W. and C.D. Bird 1977 Some Butterflies and Skippers from the Milk RiverLost River Area of Southeastern Alberta. Blue Jay 35:15-18. 